\title{
The Perruche judgment and the "right not to be born"
}

\author{
M Spriggs, J Savulescu
}

Overruling of law said to establish the "right not to be born"

\begin{abstract}
The French government has given in to public pressure and overturned a controversial legal ruling which recognised the right of a disabled chld to seek damaages. Most notably, the ruling, widely described as establishing a child's right "not to be born", had provoked "outrage" amongst groups defending the rights of the disabled and led to a ban on prenatal scans by French gynaecologists. Once again, only parents will be able to seek damages but some people think the ruling has been misinterpreted.
\end{abstract}

$\mathrm{T}$ he Perruche judgment, a controversial ruling which has been said to establish the "right not to be born", has now been overruled by a majority of the National Assembly of the French Parliament. ${ }^{12} \mathrm{~A}$ bill has been put forward which states "no one can sue for damages for the sole fact of their birth". It was considered by the senate until January 22, 2002.

In 1982, Josette Perruche discovered red spots covering her four year old daughter. The child was diagnosed with German measles. Mrs Perruche told her doctor that if she was infected, she should have an abortion rather than risk giving birth to a severely handicapped child.

Mrs Perruche underwent two blood tests, two weeks apart. Mrs Perruche's doctor assured her that it was safe to go on with the pregnancy. In fact, the tests had been contradictory. Instead of pursuing the question, Mrs Perruche's doctor reassured her. A later blood test would show that the lab had made a mistake.

Nicholas Perruche was born in 1983 deaf, part-blind and with severe brain damage. Within two years, Mrs Perruche had suffered a "nervous breakdown", requiring psychiatric care. Today the boy is cared for by a government institution. He spends alternate weekened with his divorced parents. ${ }^{3-5}$

In 2000, France's highest appeals court awarded compensation to 17 year old Nicholas Perruche. The significance of the Perruche ruling was that it recognised the child's right to seek damages allegedly for being born. Prior to that only parents could seek damages. Perruche's parents were compensated in February 1997 and then Nicholas himself was granted compensation in November 2000. The court considered there were risks in compensating only the patents because of the possibility of separation or death. ${ }^{6}$

Debate about the Perruche judgment and whether a child has the "right not to be born" was reawakened on November 28 last year when a French court awarded damages to a boy with Down's syndrome-for "being born" some are saying. ${ }^{7}$ The boy's parents had already been compensated for medical negligence, but the appeals court ordered the sum to be increased. ${ }^{8}$ The court ruled that the six year old, known only as Lionel, would have been aborted if his mother had known he would be born with a disability. Her gynaecologist "missed key signals" that Lionel had Down's syndrome."

Pressure groups defending the rights of the disabled are "outraged" by the decision. It confirmed the previous year's landmark Perruche ruling. The Catholic church has described the Perruche ruling as "a declaration that the love showered on handicapped children by countless families is worthless". ${ }^{4}$ Because Down's syndrome is considered a milder affliction, campaigners for the disabled are more outraged by the latest ruling.' In response to this ruling a spokesman for the Collective Against Handiphobia claimed: "Certain judges still believe that it is better to be dead than handi capped". ${ }^{10}$

These decisions have alarmed some doctors who say they can be "condemned for not being able to predict a malformation with $100 \%$ certainty". According to Roger Bessis, president of the French College of Echography (ultrasound scanning): "The courts said the doctor was $100 \%$ liable, but everyone knows that medicine can never be $100 \%$ accurate". ${ }^{11}$

Doctors were also concerned that children born with congenital handicaps would be divided into two classes: (1) those born as the result of medical error or whose parents said they would have had a termination of pregnancy; (2) those born as a result of better medical care or whose parents had chosen to continue with their pregnancy. Those in class (1) would receive better support through medical negligence compensation those in class (2). This constituted unfair discrimination.

On January 1, because of the fear of a growing number of lawsuits, French gynaecologists went on strike, refusing to carry out prenatal scans. ${ }^{12}$ This ban and the pressure of public opinion, an "ill-informed public opinion" according to some, has forced the government to overrule the judgments. Under the new law only the parents will be able to seek damages and "only on the grounds of a 'blatant error' by doctors": in other words, only if the doctor caused the disability or overlooked something obvious. $^{13} 14$

Some people think the Perruche ruling has been misinterpreted: "The court never said there should be damages for the mere fact of being alive. It said there should be damages for suffering", said Gilles-Jean Portejoie, a lawyer for one of the families who have benefited from the ruling. "And the child suffers not from being born-but from the disability". ${ }^{13}$

Not everyone is happy with the overturning of the Perruche ruling and the new law which means that disabled children will not be able to seek damages. It does not address the "original problem" recognised by the Perruche ruling-" the lack of state provision for disabled people, particularly those who have reached adulthood". ${ }^{13}$

\section{J Med Ethics 2002;28:63-64}

\section{Authors' affiliations}

M Spriggs, J Savulescu, Ethics Program, Murdoch Childrens Research Institute, Royal Childrens Hospital, Flemington Road, Parkville, Victoria, 3052, Australia

spriggsm@murdoch.rch.unimelb.edu.au; savulesj@cryptic.rch.unimelb.edu.au

\section{REFERENCES}

1 Anonymous. France rejects 'right not to be born'. BBC News 2002 Jan 10. Accessed 15 Jan 2002 at http://news.bbc.co.uk/hi/ english/world/europe/newsid_1752000/ $1752556 . \mathrm{stm}$

2 Anonymous. MPs respond on right not to be born, Sydney Morning Herald 2002 Jan 12. Accessed 15 Jan 2002 at http:// www.smh.com.au/news/0201/12/world/ world 16.html

3 Daley S. France bans damages for 'wrongful births'. The New York Times 2002 Jan 11. Accessed 15 Jan 2002 at http:// www.nytimes.com/2002/01/11/ international/

11 FRAN.html? ex $=1011713450$ \&ei $=1$ \&en =98c9af401 $179 \mathrm{fd} 64$ 
4 Henley J. France limits the right of those born disabled to sue doctors. Guardian Unlimited 2002 Jan 11 . Accessed 15 Jan 2002 at http://society.guardian.co.uk/health/story/ $0,7890,631073,00 . h t m l$

5 Anonymous. Boy compensated for being born. BBC News 2000 November 17. Accessed 18 Jan 182002 at http://news.bbc.co.uk/hi/english/world/ europe/newsid_1028000/1028648.stm

6 Prieur C. The supreme court of appeal affirms to defend the 'effective respect' of the handicapped child. Le Monde.fr 2002 Nov 29. Copy of electronic version available from authors on request.
7 Dorozynski A. Highest French court awards compensation for 'being born'. British Medical Journal 2001;323:1384.
8 Coomarasamy J. Down's child paid for being born. BBC News 2001 Nov 28.
Accessed 15 Jan 2002 at http:// news.bbc.co.uk/hi/english/world/europe/ newsid_1681000/1681041.stm
9 Anonymous. Storm over right not to be born. The Herald Sun 2001 Nov 30: news section: 38 .
10 Van der Laan N. France debates right not to be born. The Christian Science Monitor 2001 Dec 7. Accessed 15 Jan 2002 at http://www.csmonitor.com/2001/1207/ pls3-woeu.html

11 Jiménez $M$. 'Wrongful life' ruling outrages ethicists. National Post Online 2002 Dec 15. ethicists. National Post Online http://www. nationalpost.com/home/ story. htmlef =/stories $20011215 /$ 879049.html

12 Guilyardi C. Scan strike by French doctors BBC News 2002 Jan 3. Accessed 15 Jan 2002 at http://news.bbc.co.uk/hi/english/ health/newsid_1740000/1740380.stm

13 Schofield H. Disability ruling caused huge offence. BBC News 2002 Jan 10. Accessed 15 Jan 2002 at http://news.bbc.co.uk/hi/ english/world/europe/newsid_1753000/ 1753065.stm

14 Sutherland T. French twist on right to be born. The Weekend Australian 2002 Jan 12-13: news section: 11.

\section{New JME online submission and review system}

The Editors of the Journal of Medical Ethics are pleased to inform authors and reviewers of its new online submission and review system. Bench>Press is a fully integrated electronic system which utilises the web to allow rapid and efficient submission of manuscripts. It also allows the peer review process to be conducted entirely online.

Authors can submit their manuscript in any standard word processing software. Standard graphic formats acceptable are: .jpg, .tiff, .gif, and eps. The text and graphic files are automatically converted to PDF for ease of distribution and reviewing purposes. Authors are asked to approve their submission before it formally enters the reviewing process.

To access the system click on "SUBMIT YOUR MANUSCRIPT HERE" on the JME homepage: http://www.jmedethics.com/, or you can access Bench>Press directly at http://submit-jme.bmijournals.com/.

We are very excited with this new development and I would encourage authors and reviewers to use the online system where possible. It really is simple to use and should be a big improvement on the current peer review process. Full instructions can be found on Bench>Press http://submit-jme.bmijournals.com/, and JME online at http://www.jmedethics.com/. Please contact Natalie Davies, Project Manager, ndavies@bmigroup.com for further information. 